Article

\title{
Five-Year Field Trial of Eight Camelina sativa Cultivars for Biomass to be Used in Biofuel under Irrigated Conditions in a Semi-Arid Climate
}

\author{
Richard H. Lohaus ${ }^{1}$, Dhurba Neupane ${ }^{1}{ }^{\circledR}$, Mitiku A. Mengistu ${ }^{1}$, Juan K.Q. Solomon ${ }^{2}{ }^{\circledR}$ and \\ John C. Cushman 1,*(D) \\ 1 MS330/Department of Biochemistry \& Molecular Biology, MS 330, 1664 N. Virginia St., University of Nevada, \\ Reno, NV 89557-0330, USA; rhlohaus25@gmail.com (R.H.L.); dneupane@unr.edu (D.N.); \\ mmengistu@unr.edu (M.A.M.) \\ 2 Department of Agriculture, Veterinary \& Rangeland Sciences, University of Nevada, Reno, \\ 1664 N. Virginia Street, Reno, NV 89557, USA; juansolomon@unr.edu \\ * Correspondence: jcushman@unr.edu; Tel.: +1-775-784-1918; Fax: +1-775-784-1419
}

Received: 16 March 2020; Accepted: 9 April 2020; Published: 13 April 2020

check for updates

\begin{abstract}
Camelina sativa is a promising oilseed crop used for dietary oil and as a biofuel feedstock. C. sativa is a highly adaptable, cool season crop that can be grown on marginal lands with minimal inputs, making it potentially suitable for growth in Northern Nevada and other cooler and drier semi-arid regions of North America. A five-year (2011 to 2015) field trial was conducted to evaluate the seed yield, oil content, and oil and biodiesel production potential of eight $C$. sativa cultivars in semi-arid regions of Northern Nevada. Columbia, Cheyenne, Calena, and Blaine Creek were ranked as the top four varieties based on the five-year study of mean seed yield, oil content, and estimated oil and biodiesel production values, although none of the cultivars were significant $(p>0.05)$. Overall, Columbia displayed the highest seed yield, harvest index, oil yield and potential biodiesel production of $910 \mathrm{~kg} \mathrm{ha}^{-1}, 0.147,273.4 \mathrm{~kg} \mathrm{ha}^{-1}$, and $86.4 \mathrm{~L} \mathrm{ha}^{-1}$, respectively, across five growing seasons. For each individual year across the eight cultivars, seed yield, oil content, oil and potential biodiesel production was highest in 2015, and lowest in 2012 and 2013 (the drier years). The seed yields of this study fall within the ranges of yields reported in both the irrigated and rainfed locations of the Western United States. Based on the seed yield, oil, and the estimated oil and biodiesel productivity reported in this study, C. sativa can be grown successfully with supplemental irrigation in semi-arid environments like Nevada.
\end{abstract}

Keywords: Camelina sativa; irrigated agriculture; oilseed crop; biodiesel feedstock

\section{Introduction}

Camelina sativa, also known as false or wild flax, German sesame, gold of pleasure, and linseed dodder, is an oilseed species within the Brassicaceae. C. sativa center of diversity is in Northern Europe, the Mediterranean, and Central Asia, where it has been cultivated since Neolithic times, as a source of vegetable oil for food, lighting, medicine, and as an animal feed [1-4]. C. sativa has also received considerable interest as an alternative oilseed crop for biofuel production [5-8], particularly for on-farm biodiesel production, to increase farm income, diversify rural economies, and promote renewable biofuel use [9].

C. sativa is a rapidly maturing (85-120 days) short-season species typically planted as a winter or spring annual crop best adapted to cooler climates. C. sativa is currently grown in the traditional flax-growing regions of the Upper Midwest of the United States (i.e., Minnesota, North Dakota, South Dakota, and Montana) and Canada, among many other areas throughout the 
world including Europe, Asia, and Australia [10]. The rapid-cycling oilseed can be used in crop rotations [11,12] or in mixed intercropping systems, often with soybean, maize, or winter wheat [12-14].

Ideal candidate crops for dryland areas demonstrate the ability to adapt to abiotic stress, including limited water and fertilizer inputs. Nevada's leading cash crop is Medicago sativa (alfalfa), which is valued at about $\$ 150$ million annually [15], requires large water inputs [16]. Although a legume, alfalfa removes large amounts of minerals from the soil, and might require significant fertilizer inputs for optimum yield [17]. In contrast, C. sativa is highly adaptable and can be grown in arid and semi-arid areas in the Western and Southwestern United States [18] and on marginal, low-fertility, and saline soils [19]. C. sativa is cold-tolerant and capable of surviving late-spring freezes [10] making it suitable as an oilseed crop in Northern Nevada where such freezes can occur. Additional agronomic attributes include a high level of resistance to insect pests [20] and high nutrient-use efficiency, resulting in a low-input and inexpensive cropping system with minimal fertilizer inputs [21], without the need for fungicide or pesticide applications [22].

Field trials have been conducted in the Western United States to examine the growth and productivity responses of $C$. sativa, under rain-fed or irrigated conditions, nitrogen (and sulfur) fertilization $[21,23,24]$, sowing date or season [25-29], sowing method $[26,28,30]$, stand reduction by manual plant removal [31], location [24,29,32], and as a fallow replacement crop for winter wheat [12]. Rainfed studies using C. sativa were performed in the Intermountain West [21,23-25,31,33], the Midwest [12,34], and the Pacific Northwest US [24,28,29]. Several irrigation studies using C. sativa have also been completed in the Midwest [27,35], Southwest [36], and Western US [37,38]. Two recent studies performed in Nevada reported that $C$. sativa benefits from early season sowing using a seed drill and adequate fertilization rates [26,39]. However, the performance of multiple varieties under irrigated conditions in this region has not been fully explored. Therefore, the objective of this study was to evaluate the seed yield, oil content, and potential oil and biodiesel production of eight C. sativa cultivars, grown under semi-arid conditions in Northern Nevada.

\section{Materials and Methods}

\subsection{Field Description and Weather Conditions}

A series of varietal trials was conducted over five years (2011-2015) at the Nevada Agricultural Experiment Station at the Valley Road Field Laboratory of University of Nevada-Reno, Reno, NV. The Natural Resources Conservation Service (NRCS) described the predominant soil at this site as Orr sandy loam (taxonomic class-fine-loamy, mixed, super active, mesic Aridic Argixerolls), which are very deep, well-drained soils formed in alluvium derived from mixed igneous rocks [40]. Weather data during the five-year period of the experiment and a 29-year average (1987-2015) were recorded for accumulated monthly precipitation, mean monthly air temperature, total monthly solar radiation, and accumulated monthly growing degree days (GDD) from the Western Regional Climate Center, Desert Research Institute Weather Station (WRCC, DRIWS) [41], situated approximately $500 \mathrm{~m}$ away from the research plots (Table 1). 
Table 1. Monthly accumulated precipitation, mean air temperature, accumulated solar radiation, and growing degree-days (GDD) at the University of Nevada, Reno Valley Road Field Laboratory Reno, NV during the 2011 to 2015 growing seasons and the 29-year average (1987-2015).

\begin{tabular}{|c|c|c|c|c|c|c|c|c|c|c|c|c|}
\hline \multirow{2}{*}{ Montds } & \multicolumn{6}{|c|}{ Total Precipitation $(\mathrm{mm})$} & \multicolumn{6}{|c|}{ Mean Air Temperature $\left({ }^{\circ} \mathrm{C}\right)$} \\
\hline & 2011 & 2012 & 2013 & 2014 & 2015 & 29-Year & 2011 & 2012 & 2013 & 2014 & 2015 & 29-Year \\
\hline March & 32.51 & 2.79 & 7.37 & 2.03 & 0.25 & 8.99 & 15.0 & 15.0 & 15.6 & 13.3 & 18.3 & 15.4 \\
\hline April & 2.79 & 1.78 & 5.84 & 7.87 & 8.89 & 5.44 & 16.7 & 21.7 & 19.4 & 17.8 & 18.3 & 18.8 \\
\hline May & 10.16 & 7.62 & 17.02 & 13.72 & 25.65 & 14.83 & 18.9 & 23.3 & 22.2 & 22.8 & 23.9 & 22.2 \\
\hline June & 34.29 & 0.00 & 4.06 & 0.00 & 23.62 & 12.40 & 26.1 & 26.7 & 29.4 & 26.1 & 30.0 & 27.7 \\
\hline $\begin{array}{c}\text { Seasonal } \\
\text { precipitation }\end{array}$ & 79.76 & 12.19 & 34.29 & 23.62 & 58.42 & 41.66 & & & & & & \\
\hline $\begin{array}{l}\text { Supplemental } \\
\text { irrigation }\end{array}$ & 176.4 & 250 & 296.3 & 385 & 353 & & & & & & & \\
\hline $\begin{array}{l}\text { Total water } \\
\text { applied }\end{array}$ & 256.2 & 262.2 & 330.6 & 408.6 & 411.4 & & & & & & & \\
\hline \multirow{2}{*}{ Months } & \multicolumn{6}{|c|}{ Solar Radiation $\left(\mathrm{KW} \mathrm{m} \mathrm{m}^{-2}\right)$} & \multicolumn{6}{|c|}{ GDD } \\
\hline & 2011 & 2012 & 2013 & 2014 & 2015 & & 2011 & 2012 & 2013 & 2014 & 2015 & 29-Year \\
\hline March & 133.7 & 143.4 & 145.3 & 144.1 & 141.6 & & 9.6 & 32.8 & 76.2 & 69.0 & 124.2 & 111.5 \\
\hline April & 170.6 & 171.2 & 193.4 & 185.1 & 177.0 & & 86.5 & 142.6 & 138.6 & 158.3 & 134.6 & 203.4 \\
\hline May & 143.0 & 121.3 & 189.8 & 192.9 & 173.3 & & 164.1 & 70.0 & 193.2 & 235.3 & 261.2 & 346.9 \\
\hline June & 210.6 & 238.0 & 212.1 & 230.9 & 217.7 & & 340.5 & 390.7 & 408.3 & 408.3 & 471.0 & 458.3 \\
\hline Total & & & & & & & 600.7 & 636.1 & 816.3 & 870.9 & 991.0 & 1120.1 \\
\hline
\end{tabular}

\subsection{Treatment and Experimental Design}

Treatment included eight C. sativa (L.) (Crantz) cultivars (namely 'Blaine Creek', 'Calena', 'Celine', 'Cheyenne', 'Columbia', 'Ligena', 'Suneson', and 'Yellowstone'). Different C. sativa cultivars selected for this study were based upon their potential adaptability, genotype $\times$ environmental interaction, and yield stability across different environmental conditions [38]. C. sativa cultivars were planted in a pseudo-randomized complete block design, with six replications in each year of the five trials conducted over a five-year period [42]. The plot design ensured spatial distribution of the replicates across the field and prevented replicate cultivar adjacency in the horizontal (row), vertical (column), and diagonal dimensions. The arrangement was changed annually so that the planting locations of each cultivar differed from year to year.

\subsection{Field Establishment and Management}

Weed management is a great challenge to crop production in a semi-arid environment. Therefore, prior to seedbed preparation and sowing, pre-emergent glyphosate [N-(phosphonomethyl) glycine] was applied to the field at a rate of $1.12 \mathrm{~kg}$ a.i. $\mathrm{ha}^{-1}$, to reduce the weed infestation during the crop growing season. During the growing season, post-emergent weeds, including both grass and broadleaf weeds control was performed regularly by hand pulling.

Field trials were planted on March (5-7), during each growing season from 2011 to 2015. The individual plot size was one $\mathrm{m}^{2}$, and the catchment area was $285 \mathrm{~m}^{2}$, with $1 \mathrm{~m}$ unplanted space between each plot vertically and horizontally, and an unplanted peripheral border of $4 \mathrm{~m}$ outside the planted one $\mathrm{m}^{2}$ plots. Seeds were hand broadcast, followed by raking to a depth of approximately $6 \mathrm{~mm}$, to ensure seed-to-soil contact for uniform seed germination. In 2011, the seeding rate of $6.73 \mathrm{~kg} \mathrm{ha}^{-1}$ (800 seeds $\mathrm{m}^{-2}$ ) was used. From 2012, seeding rates were increased by $5 \%$ in each of the following years, to compensate for possible reductions in germination rates. Thus, seeding rates of $800,840,882,926$, and 972 seeds $\mathrm{m}^{-2}$ were used in 2011, 2012, 2013, 2014, and 2015, respectively. The additional $5 \%$ increase in seeding rates was based on the germination test performed at the end of the experimental year (i.e., before planting the next season).

Nitrogen $(\mathrm{N})$ fertilizer was applied in each plot using urea (46-0-0) at a rate of $52.5 \mathrm{~kg} \mathrm{~N} \mathrm{ha}^{-1}$, as a single application prior to planting. 
For irrigation management, the field site was irrigated immediately after planting, using overhead sprinklers on timers. For the first two weeks after sowing, the crop was irrigated every other day to ensure for uniform seedling emergence. After emergence, the field site was irrigated two to three times weekly, based on the field inspection for soil dryness. Previous studies have reported a sprinkler irrigation efficiency of $80 \%$ [37], depending upon wind dispersion and evaporation. To minimize the associated water loss from wind dispersion and evaporation, irrigation was scheduled in the morning hours when average wind speed was lower than $2 \mathrm{~m} \mathrm{~s}^{-1}$ (WRCC, DRIWS) [41].

The site was enclosed by steel fencing to prevent herbivory damage from rabbits. Upon termination of irrigation, two weeks prior to harvesting, netting was installed to prevent bird sampling in 2013, 2014, and 2015. No significant damage from insects, pests, or diseases were reported during the course of this study.

\subsection{Computations and Data Collection}

In order to predict the timing of crop maturity for harvesting, GDD were used. However, GDD depends upon the nature of the crop used and the weather conditions during the growing season, particularly temperature. GDD were computed using the formula described below:

$$
\mathrm{GDD}=\sum_{i=1}^{n} \frac{\mathrm{T}_{\max \_\mathrm{i}}+\mathrm{T}_{\min \_\mathrm{i}}}{2}-\mathrm{T}_{\text {base }}
$$

where $\mathrm{T}_{\max \_\mathrm{i}}, \mathrm{T}_{\min \_\mathrm{i}}$, and $\mathrm{T}_{\text {base }}$ with $\mathrm{I}=1$ through $\mathrm{n}$ number of days are the maximum, minimum, and base daily temperatures, respectively. A base temperature of $5{ }^{\circ} \mathrm{C}$, the temperature at which C. sativa can be successfully grown, was used to predict the GDD [30]. GDD were computed on a daily basis and the GDD values were added to compute GDD for each month.

Total amount of water used for C. sativa was based upon the seasonal water use (WU), which was computed using the water balance equation [43] described below:

$$
\mathrm{WU}=\sum_{i=1}^{n} \mathrm{P}+\mathrm{I} \pm \Delta \mathrm{SW} \_\mathrm{i}-\mathrm{RO}-\mathrm{DP}
$$

where $\mathrm{P}, \mathrm{I}, \Delta S \mathrm{~S} \_\mathrm{i}, \mathrm{RO}$, and DP with $\mathrm{i}=1$ through $\mathrm{n}$ number of weeks represent ambient precipitation, irrigation amount applied, weekly change in stored soil water content, surface runoff, and deep percolation, respectively. The water holding capacity of soil was very poor (approximately $3.8 \mathrm{~cm}$ ) as it was fine textured, moderately deep to duripans and ochric epipedons in nature [38]. Thus, weekly change in soil water storage between soil profile was very low (approximately zero). Runoff was not observed during the study periods of all five years, and therefore, it was considered negligible. Deep percolation was not measured in the study. Therefore, the water balance equation was modified as:

$$
\mathrm{WU}=\mathrm{P}+\mathrm{I} \ldots \ldots \ldots
$$

Plot harvest was performed manually on June 29 in 2011 and 2012, June 21 in 2013, June 30 in 2014, and June 24 in 2015, based on the predominance of beige-colored seed pods in the plots. All of the above ground biomass (including seed pods) was harvested using hedge clippers, stored in paper bags, and allowed to dry at $23.9-27.5^{\circ} \mathrm{C}$ for four months until air-equilibrated dryness occurred. After drying, the harvested seeds were threshed manually, and seeds from each plot were cleaned separately using an Almaco Air Blast Seed Cleaner (Almaco Seed Co., Model \#ABSC, Nevada, IA), and weighed to quantify the grain (seed) yield. The vegetative biomass from each plot was separately stored in labeled bags to determine the above ground biomass weight. Seed and above ground biomass dry weight was determined and recorded using an OHAUS SL Adventurer Laboratory Balance (OHAUS Corp., Parsippany, NJ, USA). To determine the $C$. sativa seed grain moisture content, $5 \mathrm{~g}$ of seeds from each 
plot were oven dried at $60{ }^{\circ} \mathrm{C}$, using an Isotemp forced-air oven (Fisher Scientific, Hampton, NH, USA). Seed yield was adjusted at $8 \%$ moisture content.

Harvest index (HI) was computed as dry grain (seed) weight, divided by the dry weight of the total aboveground biomass (seed + straw) at harvest for each plot.

Oil content (\%) of C. sativa seed from each plot was determined by analyzing $0.35 \mathrm{~g}$ of seed using Bruker Nuclear Magnetic Resonance (NMR) mq20 Analyzer (Bruker BioSpin Corporation, San Jose, CA, USA), using a calibration curve derived from purified C. sativa seed oil, according to the manufacturer's instructions.

Oil yield $\left(\mathrm{kg} \mathrm{ha}^{-1}\right)$ was computed as the product of $C$. sativa seed yield $\times \%$ seed oil content. Potential biodiesel production was evaluated based on the assumed mechanical extraction efficiency of $80 \%$ [44]. To quantify the biodiesel yield, we accounted for $10 \%$ postharvest seed loss [23]. Therefore, biodiesel yield was estimated from $90 \%$ postharvest $C$. sativa seed yield, and oil content, using the volumetric conversion factor of $1 \mathrm{~kg} \mathrm{ha}^{-1}$ to $0.439 \mathrm{~L} \mathrm{ha}^{-1}$ [44].

\subsection{Statistical Analysis}

The assumptions of normality and homogeneity of the variance test (HOVTEST) for cultivar and year, and their effect on our measured parameters (seed yield, biomass yield, oil content, and oil and biodiesel yield) were performed using the PROC GLIMMIX procedure in SAS 9.4 [45], using the restricted maximum likelihood estimation technique, with identity as the link function, and containment as the degree of freedom method [45]. The test of normality of variances using the PROC UNIVARIATE PROCEDURE in SAS 9.4 showed that the assumptions of normality were violated for our measured variables, such as seed yield, biomass yield, harvest index, oil content, and oil and biodiesel yield of the test was significant ( $p$-value for Shapiro-Wilk's W test $<0.05$ ). The HOVTEST between different cultivars for all measured parameters showed that error variances were heterogeneous ( $p$-value based on a chi-square with DF degree of freedom $<0.05$ ). Similarly, the HOVTEST between different years suggested that there was heterogeneity of error variances ( $p$-value from HOVTEST $<0.05$ ) for seed yield, harvest index, and oil and biodiesel yield, but biomass yield and oil content showed homogeneity of error variances ( $p$-value from HOVTEST > 0.05). To address heterogenous error variances, five different models, such as a model with compound symmetry, an unstructured model, Cholesky, autoregressive and autoregressive with heterogenous variance were compared based on Akaike Information Criteria (AIC), and -2 Restricted log likelihood values. The autoregressive with heterogenous variance model showed errors, suggesting that the optimization routine could not improve the function value. With the smallest AIC value and a significantly lower value of -2 Restricted log likelihood (data not shown), the Cholesky model was the best model and was used during the analysis.

The model equation for random and fixed effects [46] is described as follows:

Let $y_{\mathrm{ij}}$ represent the response from the experimental units which received treatment $\mathrm{i}$ in blocks $\mathrm{j}$.

$$
\mathrm{y}_{\mathrm{ij}}=\mu+\tau+\beta_{\mathrm{j}}+\varepsilon_{\mathrm{ij}}
$$

where $\mathrm{i}=1,2 \ldots, \mathrm{t} ; \mathrm{j}=1,2 \ldots, \mathrm{r} ; \mu$ and $\tau_{\mathrm{i}}$ are fixed parameters, such that the mean for the $\mathrm{i}^{\text {th }}$ treatment $\mu_{\mathrm{i}}=\mu+\tau_{\mathrm{i}} ; \beta_{\mathrm{j}}$ is the random effect associated with the $\mathrm{j}^{\text {th }}$ block, $\varepsilon_{\mathrm{ij}}$ is the random error associated with the experimental unit in block $\mathrm{j}$ that received treatment $\mathrm{t}$. We assumed that block effects and random error effects were normally and independently distributed with mean $=0$, and variance $=\sigma^{2}$, i.e., $\beta_{j}$ $(\mathrm{j}=1,2 \ldots, \mathrm{r})$ are distributed iid $\mathrm{N}\left(0, \sigma^{2}\right)$, and $\varepsilon_{\mathrm{ij}}(\mathrm{I}=1,2, . ., \mathrm{t}, \mathrm{j}=1,2 . ., \mathrm{r})$ are distributed iid $\mathrm{N}\left(0, \sigma^{2}\right)$.

Statistical analysis was performed by fitting the generalized linear mixed model (GLMM) for repeated data structure using the PROC GLIMMIX procedure in SAS 9.4 [45]. Cultivar and year were treated as fixed effects, while replication was considered to be a random effect. To show the repeated effect of year, we also used the random year/residual statement with subject = options in addition to the random replication statement with subject $=$ options in PROC GLIMMIX in SAS 9.4. Treating year as a fixed effect was based upon the assumption that there were variations in soil chemical properties 
and weather data at the five site-year. Gaussian distribution, identity as the link function, estimation technique of restricted maximum likelihood (REML), optimization technique of dual quasi-newton, and containment as degree of freedom method were used during the analysis. Treatment least square means (LSM) were separated at $p \leq 0.05$, using the PDIFF statement in the LSMEANS procedure of the SAS PROC GLIMMIX. $p$-values were reported based on the F-statistic from the type 3 tests of fixed effects. A Fisher's least significant difference (LSD), a test without a correction for multiple comparison, was performed. We used the lines option in the LSMEANS statement to add letter groups for multiple comparisons. The main effect of cultivar and year, and their interaction effects were reported separately for each of the measured parameters (for example, seed yield, biomass yield, harvest index, oil content, oil and biodiesel yield) with letter groups for multiple comparisons.

Statistical power is the probability of rejecting the null hypothesis when it is false (i.e., $1-\beta=$ power, $\beta$ is type II error), which is important when comparing the statistical power of different experimental designs or analysis methods used for a fixed sample size [47,48]. Power analysis was performed for each year between different cultivars (for non-significant results, when $p>0.05$ ) using the PROC GLIMMIX in SAS 9.4 [45]. As described by Stroup et al. (2002) [49], power was computed in two steps. First, the noncentral parameter (ncparm) was computed. Second, the power was determined. The ncparm was computed as the F value obtained from the assumed sill, range, and the set of treatment differences multiplied by the numerator degree of freedom. The finv function was the value of $F$ distribution for a given left-hand tail probability. Likewise, probf function determined the left-hand tail probability for a given value of $\mathrm{F}$. The right hand tail above Fcrit using the non-central $\mathrm{F}$ with $\phi=$ ncparm was thus the power of the test. The coefficient of variation (CV) was also analyzed for the measured parameter averages, across five growing seasons and eight different $C$. sativa cultivars.

\section{Results}

\subsection{Weather Data}

Weather data during the five years of the field trial and the 29-year average (1987-2015) obtained from the WRCC, DRIWS (Table 1) showed that the accumulated monthly precipitation, mean air temperature, monthly solar radiation, and GDD deviated for each growing season and from the 29-year average data (Table 1). There were minimal differences in mean monthly air temperature, among the five growing seasons and with the 29-year average air temperature. There was a $2.9^{\circ} \mathrm{C}$ higher mean air temperature in the month of April in 2012, compared to the 29-year average mean air temperature. Substantial variations in accumulated monthly precipitation was observed within each year and with the 29-year average precipitation. The highest monthly accumulated precipitation happened in the month of June in 2011, followed by May through June of 2015. However, the greater precipitation in June in 2011 did not contribute to a higher seed yield, because it occurred near harvest time. Accumulated seasonal precipitation was lowest in 2012, compared to the other growing seasons and the 29-year average precipitation (Table 1). Cumulative supplemental irrigation of 176, 250, 296, 385, and $353 \mathrm{~mm}$ were applied over the growing seasons of 2011, 2012, 2013, 2014, and 2015, respectively (Table 1). Accumulated monthly solar radiation also showed variations among the five growing seasons, with the lowest solar radiation having occurred in May 2012 (Table 1). GDD was lower in 2011 and 2012, compared to the other years, and the 29-year average GDD (Table 1). However, the lowest GDD, particularly in May 2012, appeared to negatively impact seed yield, because it occurred during the time of year that corresponded to the late flowering stage or early grain filling stage of C. sativa.

\subsection{Seed Yield}

Seed production is one of the most important agronomic traits for oilseed crops. The seed yields of C. sativa across five growing seasons was affected by year; however, it was not affected by cultivar, nor their interaction per year (cultivar $\times$ year) (Table 2). Among the different cultivars, Columbia performed 
best in terms of seed yield, compared to the other cultivars used in this study, and Celine produced the lowest seed yield, although they were not statistically different $(p>0.05$; Table 3$)$. The highest seed yield across the five years was reported in 2015 and the lowest seed yield was observed in 2012 (Table 4). Regarding each cultivar effect on seed yield across five growing seasons, Columbia produced the highest seed yield compared to the other seven cultivars, and the seed yields were higher in 2015 and 2011, but was lower in 2012 and 2013 (Table 5). Within each year, the seed yields were consistent in all years $(p>0.05)$, except for 2011. In 2011, the seed yield was highest for Columbia $\left(1204 \mathrm{~kg} \mathrm{ha}^{-1}\right)$ and lowest for Ligena $\left(412 \mathrm{~kg} \mathrm{ha}^{-1}\right)$, but the other six cultivars produced consistent seed yields (Table 5).

Table 2. F-statistic in the type 3 tests of fixed effects for seed yield, biomass yield, harvest index, oil content, and oil yield for C. sativa as affected by cultivar, year, and their interactions during the spring growing season of 2011 through 2015, at the Nevada Agricultural Experiment Station at the Valley Road Field Laboratory of University of Nevada, Reno, Reno, NV. Values are probabilities for the F-statistics. Bold fonts represent the significant effect on our measured variables.

\begin{tabular}{cccccccc}
\hline \multicolumn{7}{c}{$p$-Value } \\
\hline Effect & df & Seed Yield & Biomass Yield & Harvest Index & Oil Content & Oil Yield & Biodiesel Yield \\
\hline Cultivar & 7 & 0.88 & 0.960 & 0.059 & 0.80 & 0.86 & 0.86 \\
Year & 4 & $<\mathbf{0 . 0 0 0 1}$ & $<\mathbf{0 . 0 0 0 1}$ & $<\mathbf{0 . 0 0 0 1}$ & $<\mathbf{0 . 0 0 0 1}$ & $<\mathbf{0 . 0 0 0 1}$ & $<\mathbf{0 . 0 0 0 1}$ \\
Cultivar $\times$ Year & 28 & 0.113 & 0.827 & $<0.0001$ & $<0.0001$ & 0.049 & 0.049 \\
\hline
\end{tabular}

Table 3. The main effect of C. sativa cultivars on seed yield $\left(\mathrm{kg} \mathrm{ha}^{-1}\right)$, biomass yield $\left(\mathrm{Mg} \mathrm{ha}^{-1}\right)$, harvest index $\left(\mathrm{kg} \mathrm{kg}^{-1}\right)$, oil content $(\%)$, oil yield $\left(\mathrm{kg} \mathrm{ha}^{-1}\right)$, and biodiesel yield ( $\left.\mathrm{L} \mathrm{ha}^{-1}\right)$, grown during the spring growing season of 2011 to 2015 in Reno, Nevada, USA.

\begin{tabular}{|c|c|c|c|c|c|c|}
\hline Cultivar & $\begin{array}{c}\text { Seed Yield } \\
\left(\mathrm{kg} \mathrm{ha}^{-1}\right)\end{array}$ & $\begin{array}{c}\text { Biomass Yield } \\
\left(\mathrm{Mg} \mathrm{ha}^{-1}\right)\end{array}$ & $\begin{array}{c}\text { Harvest Index } \\
\left(\mathrm{kg} \mathrm{ha}^{-1} / \mathrm{kg} \mathrm{ha}^{-1}\right)\end{array}$ & $\begin{array}{c}\text { Oil Content } \\
(\%)\end{array}$ & $\begin{array}{l}\text { Oil Yield } \\
\left(\mathrm{kg} \mathrm{ha}^{-1}\right)\end{array}$ & $\begin{array}{c}\text { Biodiesel Yield } \\
\left(\mathrm{L} \mathrm{ha}^{-1}\right)\end{array}$ \\
\hline Columbia & 910 & 4.25 & 0.147 & 29.2 & 273.4 & 86.4 \\
\hline Cheyenne & 774 & 4.15 & 0.132 & 28.9 & 233.2 & 73.7 \\
\hline Calena & 741 & 4.66 & 0.127 & 29.3 & 224.3 & 70.9 \\
\hline Blaine Creek & 743 & 4.74 & 0.11 & 29.1 & 224.7 & 71 \\
\hline Yellowstone & 703 & 4.3 & 0.116 & 28.7 & 214.6 & 67.8 \\
\hline Suneson & 692 & 3.95 & 0.131 & 29 & 206.9 & 65.4 \\
\hline Ligena & 659 & 4.23 & 0.126 & 28.8 & 197.8 & 62.5 \\
\hline Celine & 656 & 4.24 & 0.113 & 28.6 & 192.6 & 60.9 \\
\hline${ }^{1} \mathrm{SEM}$ & 127 & 0.47 & 0.01 & 0.32 & 40.4 & 12 \\
\hline$p$-value & 0.88 & 0.96 & 0.059 & 0.8 & 0.86 & 0.86 \\
\hline Power & 0.30 & 0.20 & 0.77 & 0.33 & 0.32 & 0.32 \\
\hline
\end{tabular}

${ }^{1} \mathrm{SEM}$, standard error of the mean.

Table 4. Main effect of year on seed yield $\left(\mathrm{kg} \mathrm{ha}^{-1}\right)$, biomass yield $\left(\mathrm{Mg} \mathrm{ha}^{-1}\right)$, harvest index $\left(\mathrm{kg} \mathrm{kg}^{-1}\right)$, oil content (\%), oil yield ( $\left.\mathrm{kg} \mathrm{ha}^{-1}\right)$, and biodiesel yield ( $\mathrm{L} \mathrm{ha}^{-1}$ ) of eight $C$. sativa cultivars grown during the spring growing season of 2011 to 2015 in Reno, Nevada, USA.

\begin{tabular}{|c|c|c|c|c|c|c|}
\hline Cultivar & $\begin{array}{l}\text { Seed Yield } \\
\left(\mathrm{kg} \mathrm{ha}^{-1}\right)\end{array}$ & $\begin{array}{l}\text { Biomass Yield } \\
\left(\mathrm{Mg} \mathrm{ha}^{-1}\right)\end{array}$ & $\begin{array}{c}\text { Harvest Index } \\
\left(\mathrm{kg} \mathrm{ha}^{-1} / \mathrm{kg} \mathrm{ha}^{-1}\right)\end{array}$ & $\begin{array}{l}\text { Oil Content } \\
(\%)\end{array}$ & $\begin{array}{l}\text { Oil Yield } \\
\left(\mathrm{kg} \mathrm{ha}^{-1}\right)\end{array}$ & $\begin{array}{l}\text { Biodiesel Yield } \\
\quad\left(\mathrm{L} \mathrm{ha}^{-1}\right)\end{array}$ \\
\hline 2011 & $751^{1 \mathrm{c}} \pm 41$ & $3.93^{b} \pm 0.12$ & $0.157^{b} \pm 0.006$ & $29.1^{c} \pm 0.10$ & $219.4^{\mathrm{c}} \pm 12.0$ & $69.4^{c} \pm 3.8$ \\
\hline 2012 & $76^{\mathrm{e}} \pm 8$ & $2.76^{c} \pm 0.21$ & $0.027^{\mathrm{d}} \pm 0.002$ & $26.6^{\mathrm{e}} \pm 0.25$ & $20.1^{\mathrm{e}} \pm 2.0$ & $6.3^{e} \pm 0.6$ \\
\hline 2013 & $269^{d} \pm 47$ & $4.52^{c} \pm 0.35$ & $0.044^{c} \pm 0.04$ & $28.0^{\mathrm{d}} \pm 0.26$ & $75.4^{\mathrm{d}} \pm 13.2$ & $23.8^{\mathrm{d}} \pm 4.2$ \\
\hline 2014 & $998^{b} \pm 116$ & $3.64^{b} \pm 0.36$ & $0.211^{a} \pm 0.013$ & $30.1^{b} \pm 0.28$ & $\begin{array}{c}298.4^{b} \pm \\
34.7\end{array}$ & $94.3^{b} \pm 11.0$ \\
\hline 2015 & $1589^{\mathrm{a}} \pm 134$ & $6.77^{a} \pm 0.46$ & $0.186^{\mathrm{a}} \pm 0.006$ & $30.8^{a} \pm 0.14$ & $490.3^{a} \pm 41.3$ & $155.0^{\mathrm{a}} \pm 13.1$ \\
\hline$p$-value & $<0.0001$ & $<0.0001$ & $<0.0001$ & $<0.0001$ & $<0.0001$ & $<0.0001$ \\
\hline
\end{tabular}

${ }^{1}$ Within columns, mean values followed by same lowercase letter superscripts \pm SEM (Standard error of the mean) are not different between years $(p>0.05)$. Bold fonts represent significant difference between years $(p<0.05)$. 
Table 5. Interaction effect of cultivar $\times$ year on seed yield $\left(\mathrm{kg} \mathrm{ha}^{-1}\right)$ and biomass yield $\left(\mathrm{Mg} \mathrm{ha}^{-1}\right)$ of the eight C. sativa cultivars grown during the spring growing season of 2011 to 2015 in Reno, Nevada, USA.

\begin{tabular}{|c|c|c|c|c|c|}
\hline \multicolumn{6}{|c|}{ Seed Yield (kg ha $\left.{ }^{-1}\right)$} \\
\hline \multirow{2}{*}{${ }^{3}$ Cultivar } & \multicolumn{5}{|c|}{ Year } \\
\hline & 2011 & 2012 & 2013 & 2014 & 2015 \\
\hline Columbia & $1204^{1 \mathrm{ABa}}$ & $87^{\mathrm{D} 2 \mathrm{ab}}$ & $333^{C D}$ & $1004^{B C}$ & $1921^{\mathrm{A}}$ \\
\hline Cheyenne & $766^{\mathrm{Bb}}$ & $66^{\mathrm{Cb}}$ & $132^{C}$ & $1070^{\mathrm{B}}$ & $1781^{\mathrm{A}}$ \\
\hline Calena & $803^{\mathrm{Bb}}$ & $89 C^{a b}$ & $231^{C}$ & $832^{\mathrm{B}}$ & $1753^{A}$ \\
\hline Blaine Creek & $653^{\mathrm{BCbc}}$ & $52 \mathrm{Cb}$ & $241^{C}$ & $1213^{\mathrm{AB}}$ & $1555^{\mathrm{A}}$ \\
\hline Yellowstone & $571 \mathrm{BCbc}$ & $84 \mathrm{Cab}$ & $274^{C}$ & $1254^{\mathrm{AB}}$ & $1459^{\mathrm{A}}$ \\
\hline Suneson & $758^{A B b}$ & $68 \mathrm{Cb}$ & $490 B^{C}$ & $954 \mathrm{AB}$ & $1191^{\mathrm{A}}$ \\
\hline Ligena & $412^{\mathrm{BCc}}$ & $34 \mathrm{Cb}$ & $196^{C}$ & $995^{\mathrm{B}}$ & $1657^{\mathrm{A}}$ \\
\hline Celine & $839 \mathrm{ABb}$ & $126^{\mathrm{Ba}}$ & $253^{\mathrm{B}}$ & $720^{\mathrm{AB}}$ & $1343^{\mathrm{A}}$ \\
\hline${ }^{4}$ SEM & 116 & 21 & 133 & 323 & 376 \\
\hline$p$-value & 0.001 & 0.075 & 0.213 & 0.93 & 0.69 \\
\hline Power & 0.98 & 0.71 & 0.53 & 0.14 & 0.24 \\
\hline \multicolumn{6}{|c|}{ Biomass Yield $\left(\mathrm{Mg} \mathrm{ha}^{-1}\right)$} \\
\hline \multirow{2}{*}{${ }^{3}$ Cultivar } & \multicolumn{5}{|c|}{ Year } \\
\hline & 2011 & 2012 & 2013 & 2014 & 2015 \\
\hline Blaine Creek & $3.95^{1 \mathrm{~B}}$ & $3.12^{\mathrm{B}}$ & $4.20^{\mathrm{B}}$ & $4.11^{\mathrm{B}}$ & $8.34^{\mathrm{A}}$ \\
\hline Calena & $4.34^{\mathrm{B}}$ & $3.47^{\mathrm{B}}$ & $4.35^{\mathrm{B}}$ & $2.92^{\mathrm{B}}$ & $8.22^{\mathrm{A}}$ \\
\hline Yellowstone & 4.44 & 2.57 & 4.61 & 3.81 & 6.05 \\
\hline Columbia & $3.64^{\mathrm{BC}}$ & $2.44^{\mathrm{C}}$ & $5.10^{\mathrm{AB}}$ & $4.27 \mathrm{ABC}$ & $5.79 \mathrm{~A}$ \\
\hline Celine & $4.10^{\mathrm{A}}$ & $3.03^{\mathrm{A}}$ & $4.45^{\mathrm{A}}$ & $3.67^{\mathrm{A}}$ & $5.96^{\mathrm{A}}$ \\
\hline Ligena & $3.54^{\mathrm{B}}$ & $2.31^{\mathrm{B}}$ & $4.55^{\mathrm{B}}$ & $2.96^{\mathrm{B}}$ & $7.80^{\mathrm{A}}$ \\
\hline Cheyenne & $4.00 \mathrm{~A}$ & 2.52 & 3.46 & 4.09 & 6.54 \\
\hline Suneson & $3.47^{\mathrm{AB}}$ & $2.64^{\mathrm{B}}$ & $5.40^{\mathrm{A}}$ & $3.30 \mathrm{AB}$ & $4.95 \mathrm{AB}$ \\
\hline${ }^{4} \mathrm{SEM}$ & 0.35 & 0.61 & 1.01 & 1.04 & 1.33 \\
\hline$p$-value & 0.177 & 0.159 & 0.347 & 0.885 & 0.252 \\
\hline Power & 0.56 & 0.58 & 0.43 & 0.16 & 0.49 \\
\hline $\begin{array}{c}\text { Cultivars' } \\
\text { mean }\end{array}$ & $3.93^{B}$ & $2.76^{\mathrm{C}}$ & $4.52^{\mathrm{B}}$ & $3.64^{\mathrm{B}}$ & $6.77^{\mathrm{A}}$ \\
\hline
\end{tabular}

${ }^{1}$ Within rows, mean values followed by same uppercase letter superscripts are not different between years $(p>0.05)$. ${ }^{2}$ Within columns, mean values followed by same lowercase letter superscripts are not different between cultivars $(p>0.05) .{ }^{3}$ Cultivars rank top to bottom (Calena to Celine) based on five-year mean values although they were not significantly different $(p>0.05)$. Bold fonts represent significant different between years (within rows) and cultivars (within columns). ${ }^{4}$ SEM, standard error of the mean.

\subsection{Biomass Yield}

Above ground biomass production is typically not an important parameter for oilseed production, but in dryland systems, crop residues could be beneficial for promoting the soil's water-holding capacity, through the addition of organic matter. For biomass yield, there was a main effect of year, but the cultivar and interactions (cultivar $\times$ year) were not significant across the five growing seasons (Table 2). On average, across the five-year study, the biomass yield was highest in $2015\left(6.72 \mathrm{Mg} \mathrm{ha}^{-1}\right)$ and lowest in 2012 (2.76 Mg ha-1) (Table 4). Among cultivars, Blaine Creek produced the highest biomass yield compared to the other seven cultivars, although they were not statistically significant $(p>0.05$; Table 3). For each cultivar effect, all cultivars except Cheyenne, Columbia, and Yellowstone produced significantly more biomass across the five growing seasons than the other cultivars (Table 5). Among the eight cultivars evaluated in this study, Yellowstone, Calena, and Cheyenne produced higher biomass yields in 2011, 2012, and 2013, respectively. However, biomass yield was consistent among all cultivars in 2014. Notably, in 2015, Suneson produced the lowest biomass yield compared to the other cultivars (Table 5). The biomass yield values were consistent within all years $(p>0.05)$. 


\subsection{Harvest Index (HI)}

There was a main effect of year and cultivar $\times$ year interaction on $\mathrm{HI}$ among the $C$. sativa cultivars grown across five different seasons (Table 2). The HI was greatest in 2014 and lowest in 2012 and 2013 (Table 4). Regarding the interaction effect, the HI was higher for Ligena in 2014, followed by Columbia in 2011, and was lower for all cultivars in 2012 and 2013 (Table 6). Among cultivars, there was a trend in the significance effect ( $p=0.059$; Table 3$)$, with Columbia being higher, as compared to the other seven cultivars. Within each of the individual cultivars, HI was different only in years 2011, 2012, and 2015, Columbia being higher in 2011, Celine and Cheyenne in 2012, and Columbia in 2015 (Table 6).

Table 6. Interaction effect of cultivar $\times$ year on harvest index $\left(\mathrm{kg} \mathrm{kg}^{-1}\right)$ of eight $C$. sativa cultivars grown during the spring growing season of 2011 to 2015 in Reno, Nevada, USA.

\begin{tabular}{|c|c|c|c|c|c|}
\hline \multirow{2}{*}{${ }^{3}$ Cultivar } & \multicolumn{5}{|c|}{ Year } \\
\hline & 2011 & 2012 & 2013 & 2014 & 2015 \\
\hline Columbia & $0.245^{1 \mathrm{Aa}}$ & $0.039^{\mathrm{C} 2 \mathrm{a}}$ & $0.053^{C}$ & $0.169^{\mathrm{B}}$ & $0.238 \mathrm{Aa}$ \\
\hline Cheyenne & $0.162^{1 \mathrm{Bb}}$ & $0.032^{\mathrm{C} 2 \mathrm{a}}$ & $0.034^{\mathrm{C}}$ & $0.224^{\mathrm{A}}$ & $0.205^{\mathrm{Aab}}$ \\
\hline Suneson & $0.180 \mathrm{Ab}$ & $0.027^{\mathrm{Babc}}$ & $0.054^{\mathrm{B}}$ & $0.204^{\mathrm{A}}$ & $0.190 \mathrm{Abc}$ \\
\hline Calena & $0.154^{\mathrm{Bbc}}$ & $0.025^{C a b c}$ & $0.038^{C}$ & $0.236^{\mathrm{A}}$ & $0.179 \mathrm{Bbc}$ \\
\hline Ligena & $0.103^{\mathrm{BCd}}$ & $0.016^{\mathrm{Cc}}$ & $0.039^{C}$ & $0.293^{A}$ & $0.178^{\mathrm{Bbc}}$ \\
\hline Yellowstone & $0.110^{\mathrm{Bcd}}$ & 0.029 Cabc & $0.050^{C}$ & $0.216^{\mathrm{A}}$ & $0.181 \mathrm{Abc}$ \\
\hline Celine & $0.170 \mathrm{Ab}$ & $0.040^{\mathrm{Ba}}$ & $0.045^{\mathrm{B}}$ & $0.154^{\mathrm{A}}$ & $0.159 \mathrm{Abc}$ \\
\hline Blaine Creek & $0.142 \mathrm{Bbcd}$ & $0.017 \mathrm{Cbc}$ & $0.038^{C}$ & $0.199 \mathrm{~A}$ & $0.153^{\mathrm{ABC}}$ \\
\hline${ }^{3} \mathrm{SEM}$ & 0.016 & 0.005 & 0.012 & 0.036 & 0.016 \\
\hline$p$-value & & & $<0.0001$ & & \\
\hline
\end{tabular}

${ }^{1}$ Within rows, mean values followed by same uppercase letter superscripts are not different between years $(p>0.05)$. ${ }^{2}$ Within columns, mean values followed by same lowercase letter superscripts are not different between cultivars $(p>0.05)$. Bold fonts represent significant difference between years (within rows) and cultivars (within columns). ${ }^{3} \mathrm{SEM}$, standard error of the mean.

\subsection{Oil Content, Oil Yield, and Biodiesel Yield}

There was a main effect of year and cultivar $\times$ year interaction on the average oil content of C. sativa cultivars grown across five different seasons; however, no effect of cultivar was observed in this study (Table 2). The average across the five-year study for oil content in the $C$. sativa cultivars was highest in 2015 and lowest in 2012 (Table 4). Among cultivars, Calena produced the highest oil content, followed by Columbia, compared with the other cultivars in this study (Table 3). Regarding the interaction effect, within each cultivar, oil content was higher in Calena in 2014 and 2015, in Columbia in 2011 and 2015, in Blaine Creek in 2014 and 2015, in Suneson in 2013, 2014, and 2015, in Cheyenne in 2014 and 2015, in Ligena in 2015, in Yellowstone in 2014 and 2015, and in Celine in 2011 and 2014 (Table 7). Within each year among the different cultivars, oil content was higher for Columbia and Suneson in 2011, Columbia in 2012, Suneson and Ligena in 2013, Calena in 2014, and Ligena in 2015, respectively (Table 7).

For the average across the five growing seasons, there was a main effect of year and an interaction effect of cultivar $\times$ year on oil yield, but cultivar did not show any significant differences on oil yield (Table 2). Regarding the year effect, oil yield production was highest in 2015, compared to the other years. However, it was lowest in 2012 and 2013 (Table 4). Numerically, Columbia produced a higher oil yield compared to the other cultivars, although this difference was not statistically significant ( $p>0.05$; Table 3). Within each individual cultivar, oil yield was higher for Columbia, Cheyenne, Calena, and Ligena in 2015, and for Blaine Creek and Yellowstone in both 2014 and 2015. Similarly, Suneson and Celine produced a higher oil yield in 2011, 2014, and 2015. Within each year, oil yield was significantly different only in 2011, and it was highest for Columbia compared to the other cultivars evaluated in this study (Table 8). 
Table 7. Interaction effect of the Cultivar $\times$ Year on the oil content $(\%)$ of eight $C$. sativa cultivars grown during the spring growing season of 2011 to 2015 in Reno, Nevada, USA.

\begin{tabular}{|c|c|c|c|c|c|}
\hline \multirow{2}{*}{${ }^{3}$ Cultivar } & \multicolumn{5}{|c|}{ Year } \\
\hline & 2011 & 2012 & 2013 & 2014 & 2015 \\
\hline Calena & $29.38^{1 \mathrm{~B} 2 \mathrm{bc}}$ & $26.54^{C}$ & $27.84^{\mathrm{BCbc}}$ & $31.50^{\mathrm{A}}$ & $31.06^{\mathrm{Aab}}$ \\
\hline Columbia & $29.91 \mathrm{ABa}$ & $28.40^{\mathrm{CD}}$ & $27.42 \mathrm{Dbcd}$ & $29.36^{\text {BC }}$ & $30.73 \mathrm{Abc}$ \\
\hline Blaine Creek & $28.84^{\text {Bde }}$ & $25.90^{C}$ & 28.89 Bab & $30.50^{\mathrm{A}}$ & 31.27 Aab \\
\hline Suneson & $29.88^{\mathrm{Bab}}$ & $25.65^{\mathrm{B}}$ & $29.74 \mathrm{Aa}$ & $29.36^{\mathrm{A}}$ & $30.23 \mathrm{Acd}$ \\
\hline Cheyenne & 29.17 Bcde & $26.65^{C}$ & $26.29 \mathrm{Cd}$ & $30.87^{\mathrm{A}}$ & $31.35^{\mathrm{Aab}}$ \\
\hline Ligena & $27.43 \mathrm{Cf}$ & $26.80^{C}$ & $29.60 \mathrm{Ba}$ & $28.27^{\mathrm{BC}}$ & $31.85^{\mathrm{Aa}}$ \\
\hline Yellowstone & $28.71^{\mathrm{Be}}$ & $26.50^{C}$ & $27.52 \mathrm{Cbcd}$ & $30.66^{\mathrm{A}}$ & $30.22 \mathrm{Acd}$ \\
\hline Celine & $29.25^{\text {Acd }}$ & $26.73^{B}$ & $27.06^{\mathrm{Bcd}}$ & 29.92 A & $29.80^{\mathrm{Ad}}$ \\
\hline${ }^{3} \mathrm{SEM}$ & 0.26 & 0.71 & 0.75 & 0.79 & 0.39 \\
\hline$p$-value & & & $<0.0001$ & & \\
\hline
\end{tabular}

${ }^{1}$ Within rows, mean values followed by same uppercase letter superscripts are not different between years $(p>$ 0.05). ${ }^{2}$ Within columns, mean values followed by the same lowercase letter superscripts are not different between cultivars $(p>0.05)$. Bold font represents significant difference between years (within rows) and cultivars (within columns). ${ }^{3} \mathrm{SEM}$, standard error of the mean.

Table 8. Interaction effect of cultivar $\times$ year on oil yield $\left(\mathrm{kg} \mathrm{ha}^{-1}\right)$ and biodiesel yield $\left(\mathrm{L} \mathrm{ha}^{-1}\right)$ of the eight C. sativa cultivars grown during the spring growing season of 2011 to 2015 in Reno, Nevada, USA.

\begin{tabular}{|c|c|c|c|c|c|}
\hline \multicolumn{6}{|c|}{ Oil Yield (kg ha-1) } \\
\hline \multirow{2}{*}{${ }^{3}$ Cultivar } & \multicolumn{5}{|c|}{ Year } \\
\hline & 2011 & 2012 & 2013 & 2014 & 2015 \\
\hline Columbia & $360.2^{1 \mathrm{~B} 2 \mathrm{a}}$ & $23.9^{\mathrm{D}}$ & $94.1^{C D}$ & $294.3^{B C}$ & $594.3^{\mathrm{A}}$ \\
\hline Cheyenne & $223.6^{\mathrm{BCb}}$ & $17.6^{\mathrm{D}}$ & $34.4 \mathrm{CD}$ & $332.1^{\mathrm{B}}$ & $566.8^{\mathrm{A}}$ \\
\hline Blaine Creek & $188.0^{\mathrm{BCbc}}$ & $13.2^{\mathrm{C}}$ & $69.2^{C}$ & $367.3^{\mathrm{AB}}$ & $485.5^{\mathrm{A}}$ \\
\hline Calena & $235.5^{\mathrm{Bb}}$ & $23.5^{\mathrm{C}}$ & $57.4^{\mathrm{C}}$ & $262.2^{\mathrm{B}}$ & $542.7^{\mathrm{A}}$ \\
\hline Yellowstone & $163.9^{\mathrm{BCbc}}$ & $22.1^{\mathrm{C}}$ & $79.0^{C}$ & $369.3^{\mathrm{AB}}$ & $442.1^{\mathrm{A}}$ \\
\hline Suneson & $225.8^{\mathrm{ABb}}$ & $17.0^{\mathrm{C}}$ & $144.6^{\mathrm{BC}}$ & $284.5^{\mathrm{AB}}$ & $362.7^{\mathrm{A}}$ \\
\hline Ligena & $113.2^{\mathrm{BCC}}$ & $9.1^{C}$ & $58.0^{\mathrm{C}}$ & $281.3^{\mathrm{B}}$ & $527.8^{\mathrm{A}}$ \\
\hline Celine & $245.4^{\mathrm{ABb}}$ & $34.1^{\mathrm{B}}$ & $68.5^{\mathrm{B}}$ & $215.4^{\mathrm{AB}}$ & $400.8^{\mathrm{A}}$ \\
\hline${ }^{3} \mathrm{SEM}$ & 34.0 & 5.5 & 37.4 & 96.8 & 115.6 \\
\hline$p$-value & & & 0.049 & & \\
\hline \multicolumn{6}{|c|}{ Biodiesel Yield $\left(\mathrm{L} \mathrm{ha}^{-1}\right)$} \\
\hline \multirow{2}{*}{${ }^{3}$ Cultivar } & \multicolumn{5}{|c|}{ Year } \\
\hline & 2011 & 2012 & 2013 & 2014 & 2015 \\
\hline Columbia & $113.8^{1 \mathrm{~B} 2 \mathrm{a}}$ & $7.6^{\mathrm{D}}$ & $29.8^{\mathrm{CD}}$ & $93.0^{\mathrm{BC}}$ & $187.9^{\mathrm{A}}$ \\
\hline Cheyenne & $70.7^{\mathrm{BCb}}$ & $5.6^{\mathrm{D}}$ & $10.9^{C D}$ & $105.0^{\mathrm{B}}$ & $179.1^{\mathrm{A}}$ \\
\hline Blaine Creek & $59.4^{\mathrm{BCbc}}$ & $4.2^{\mathrm{C}}$ & $21.9^{C}$ & $116.1^{\mathrm{AB}}$ & $153.5^{\mathrm{A}}$ \\
\hline Calena & $74.4^{\mathrm{Bb}}$ & $7.4^{\mathrm{C}}$ & $18.1^{\mathrm{C}}$ & $82.9^{\mathrm{B}}$ & $171.5^{\mathrm{A}}$ \\
\hline Yellowstone & $51.8^{\mathrm{BCbc}}$ & $7.0^{\mathrm{C}}$ & $25.0^{C}$ & $114.0 \mathrm{AB}$ & $139.7^{\mathrm{A}}$ \\
\hline Suneson & $71.4^{\mathrm{ABb}}$ & $5.4^{\mathrm{Cb}}$ & $45.7^{\mathrm{BC}}$ & $89.9^{\mathrm{AB}}$ & $114.6^{\mathrm{A}}$ \\
\hline Ligena & $35.8^{\mathrm{BCc}}$ & $2.9^{\mathrm{C}}$ & $18.3^{C}$ & $88.8^{\text {B }}$ & $166.8^{\mathrm{A}}$ \\
\hline Celine & $77.5^{\mathrm{ABb}}$ & $10.8^{\mathrm{B}}$ & $20.9^{B}$ & $68.4^{\mathrm{AB}}$ & $126.7^{\mathrm{A}}$ \\
\hline${ }^{3} \mathrm{SEM}$ & 10.7 & 1.75 & 11.8 & 30.6 & 36.5 \\
\hline$p$-value & & & 0.049 & & \\
\hline
\end{tabular}

${ }^{1}$ Within rows, the mean values followed by same uppercase letter superscripts are not different between years $(p>0.05) .{ }^{2}$ Within columns, mean values followed by same lowercase letter superscripts are not different between cultivars $(p>0.05)$. Bold fonts represent significant difference between years (within rows) and cultivars (within columns). ${ }^{3}$ SEM, standard error of the mean. 
Potential biodiesel production was affected by year and an interaction of cultivar $\times$ year, but it was not affected by cultivar (Table 2). Biodiesel production was highest in 2015 and lowest during the 2012 and 2013 growing seasons (Table 4). With respect to cultivars effect, Columbia produced a higher biodiesel estimated amount, compared to the other cultivars evaluated in this study, although these differences were not statistically significant $(p>0.05$; Table 3). For individual cultivar effect between different years, biodiesel production followed a similar pattern to the oil yield reported in this study. For example, biodiesel production was higher for Columbia, Cheyenne, Calena and Ligena in 2015, Blaine Creek and Yellowstone in both years of 2014 and 2015. Similarly, cultivars Suneson and Celine produced a higher oil yield in the years 2011, 2014, and 2015. Within each year, biodiesel production was different only in the year 2011, and it was highest for Columbia compared to the other cultivars (Table 8).

\subsection{Power of the Experiment}

Statistical power analysis of the experiment was performed for seed yield and biomass yield for each growing season (Table 5). For seed yield, statistical power was sufficiently large only in the year 2011, which was above the acceptable threshold value of 0.80 [48]. With respect to biomass yield, across all five years, power was significantly lower than the threshold value. Similarly, statistical power average for all the measured parameters across eight $C$. sativa cultivars (Table 3 ) was significantly lower than the threshold value of 0.80 [48].

\subsection{Coefficient of Variation}

Coefficient of variations across the five growing seasons and among the eight $C$. sativa cultivars for seed yield, biomass yield, harvest index, oil content, oil, and biodiesel yields were 105.19, 59.53, $74.13,7.62,107.64$, and 107.64, respectively.

\subsection{Other Field Trials}

In order to place the relative performance of the eight $C$. sativa varieties tested in the current study in the context of other studies performed in the arid Western United States, the overall mean seed yields over the five-year growing seasons were compared with three other irrigated C. sativa varietal field trials and twelve other rainfed C. sativa varietal field trials (Table 9). While the annual mean precipitation (and applied irrigation) varied widely, the current study ranked as the second lowest mean annual precipitation $(165.1 \mathrm{~mm}$ ) compared to the other fifteen studies (Table 9). While the current study was the second driest by annual ambient precipitation (Maricopa, Arizona) was drier than our growing conditions), the current study ranked 11th, when both growing season precipitation and applied irrigation were considered. Notably, the current study had the widest seed yield range (76-1586 kg ha $\left.{ }^{-1}\right)$ and the third lowest mean seed yield $\left(736.4 \mathrm{~kg} \mathrm{ha}^{-1}\right)$, compared to these other studies (Table 9). 
Table 9. Mean seed yield of the eight C. sativa cultivars grown in Reno, Nevada, 2011-2015 (this study), compared to other field trials.

\begin{tabular}{|c|c|c|c|c|c|c|c|c|}
\hline Location & $\begin{array}{l}\text { Number of } \\
\text { Years (Trials) }\end{array}$ & Year Range & $\begin{array}{l}\text { Mean Annual } \\
\text { Precipitation } \\
\quad(\mathrm{mm})\end{array}$ & $\begin{array}{l}\text { Seasonal Precipitation and } \\
\text { Irrigation } \\
(\mathrm{mm})\end{array}$ & $\begin{array}{c}\text { Nitrogen } \\
\text { Applied } \\
\left(\mathrm{kg} \mathrm{ha}^{-1}\right)\end{array}$ & $\begin{array}{l}\text { Seed Yield Range } \\
\left(\mathrm{kg} \mathrm{ha}^{-1}\right)\end{array}$ & $\begin{array}{c}\text { Mean Seed } \\
\text { Yield } \\
\left(\mathrm{kg} \mathrm{ha}^{-1}\right)\end{array}$ & Citation \\
\hline Hays, KS & $3(3)$ & 2013-2015 & 541.0 & $350.5^{*}$ & 56.0 & 447.2 & 447.2 & [32] \\
\hline Hays, KS & $2(2)$ & 2014-2015 & 431.8 & 353.1 * & 44.8 & $424-908$ & 666.9 & [12] \\
\hline Reno, NV & $5(40)$ & 2011-2015 & 165.1 & 337.8 & 52.5 & $76-1586$ & 736.4 & This study \\
\hline Sheridan, WY & $2(2)$ & 2014-2015 & 513.1 & 251.5 * & 44.8 & $852-975$ & 913.5 & [12] \\
\hline Scottsbluff, NE & $2(4)$ & 2005-2006 & 401.3 & 431.8 & 44.8 & 555-1454 & 1061.4 & [27] \\
\hline Maricopa, AZ & $2(4)$ & 2006-2007 & 137.2 & 342.9 & 49.9 & $1026-1221$ & 1135.4 & [36] \\
\hline Mocccasin/Pendroy, MT & $3(7)$ & 2013-2015 & 386.1 & 223.5 * & 44.8 & $1095-1258$ & 1212.8 & [33] \\
\hline Sheridan, WY & $2(2)$ & 2013-2014 & 411.5 & $228.6^{*}$ & 44.8 & 988.6 & 988.6 & [25] \\
\hline Sheridan, WY & $3(3)$ & 2013-2015 & 414.0 & $248.9^{*}$ & 56.0 & 789-1539 & 1107.4 & [23] \\
\hline Huntley, MT & $2(2)$ & 2008-2009 & 393.7 & 226.1 * & 34.0 & $972-1684$ & 1327.1 & [31] \\
\hline Pendleton, OR & $3(6)$ & 2008-2010 & 421.6 & 198.1 * & 44.8 & $1296-1769$ & 1543.4 & [28] \\
\hline Corvallis, OR & $3(3)$ & 2008-2010 & 990.6 & $320.0 *$ & 44.8 & $1561-1593$ & 1577.0 & [24] \\
\hline Pendleton, OR & $3(3)$ & $2008-2010$ & 421.6 & 188.0 * & 45.0 & $1628-1707$ & 1658.3 & [29] \\
\hline $\begin{array}{c}\text { Moscow, ID/Pullman, } \\
\text { WA }\end{array}$ & $3(3)$ & 2008-2010 & 736.6 & $322.6 *$ & 44.8 & $1658-1697$ & 1677.9 & [24] \\
\hline Pendleton, OR & $3(3)$ & 2008-2010 & 421.6 & $215.9^{*}$ & 50.0 & $1760-1791$ & 1775.5 & [24] \\
\hline Scottsbluff/Sidney, NE & $2(4)$ & 2007-2008 & 360.7 & 431.8 & 41.9 & 2538.7 & 2538.7 & [35] \\
\hline
\end{tabular}




\section{Discussion}

The results from this study revealed that Columbia displayed the highest seed yield average across the five growing seasons, although no significant differences were apparent in seed yield, biomass yield, oil content, harvest index, and estimated oil and biodiesel yield for the eight spring cultivars evaluated, which was likely to be due to the greater level of dispersion around the mean of the different $C$. sativa cultivars (Coefficient of variation $>1$ ). These results were similar to those collected from the evaluation of six different spring $C$. sativa cultivars evaluated under the rain-fed conditions in Montana [33]. The lack of differences in performance was likely due to the need to improve these production traits in available commercial C. sativa cultivars [33]. However, the yields of all varieties fell within the range of yields reported in both, the irrigated [27,36] and rainfed [12,23-25,31,32,34] field trials performed in the Western United States. A pseudorandomized field design was selected for this study to ensure the spatial distribution of replicates within the field and to prevent replicate adjacency in row, column, and diagonal dimensions. However, this design could be improved upon in future studies, through the adoption of design strategies that ensured the evenness of spatial distribution of treatment replication, while also guaranteeing neighbor balance [50].

\subsection{Effect of Irrigation on Seed Yield}

Global warming is projected to lower the rates of natural precipitation in semi-arid and arid regions, leading to increased frequency of drought and soil aridity in the future [51]. Warmer temperatures will also lead to lower winter water storage capacity and a shift in river runoff, away from summer and autumn when water demand is highest [52]. Such changes are predicted to lead to declines in crop production during the $21^{\text {st }}$ century [53]. Therefore, to compensate the water lost via evapotranspiration and to optimize crop production in the semi-arid region of Northern Nevada, supplementary irrigation is vital. The Reno field trial site in Northern Nevada, received $165.1 \mathrm{~mm}$ mean annual precipitation [54] for the 2011-2015 field trial years, which was the second lowest among all sites, except for Maricopa, AZ [36]. Accumulated seasonal precipitation was highest in 2011 (a wet year), followed by 2015. In terms of total precipitation received during the growing seasons, years 2012 through 2014 were considered drier years (Table 1). Although total seasonal ambient precipitation was highest in 2011, seed yields were higher in 2014 and 2015 by $32.9 \%$ and $111.2 \%$, respectively, compared to the seed yield produced in 2011. Year 2014 showed a substantially lower precipitation than the 29-year average precipitation; however, seed yield was improved, as more irrigation was applied. Around $43 \%$ of ambient precipitation in 2011 (34.29 mm out of $79.76 \mathrm{~mm}$ ) occurred in the month of June (Table 1), which was not expected to negatively impact seed yield, because it occurred at a time when the crop was ready for harvesting. Lower mean monthly air temperature, lower solar radiation during the $C$. sativa flowering to the grain filling stage (April-May), and lower seasonal GDD in 2011 compared to 2014 and 2015, were among the possible climatic factors that might explain the lower seed yield in 2011. Similarly, the lower seed yields observed in 2012 and 2013 could also have been due to the above-mentioned factors, particularly lower seasonal precipitation and lower seasonal GDD (particularly in May) in both growing seasons (Table 1). These suggestions were consistent with multiple reports that showed that water deficit interferes with reproduction in crop plants, thereby reducing grain yields [35,55-57]. Due to the sandy clay nature of soil, factors such as change in stored soil water content, run off, and deep percolation were minimal (approximately zero) in our field plot sites. In addition, the field plot used in this study is known to have a hardpan layer (duripans) beneath a few inches of soil [40]. Therefore, the higher precipitation observed in the previous year was not likely to contribute to crop growth in the next year. This observation would explain the lower seed yield in 2012 and 2013, although a higher precipitation was recorded in 2011, particularly during the time when C. sativa was ready to harvest. Additionally, variations in seed yields of the C. sativa cultivars in different years or different sites would likely be due to the confounding effects of year or site, for example, variations in the soil's physical and chemical properties (e.g., soil bulk density, nitrogen, phosphorous, potassium, micronutrients, and cation exchange capacity). Lower power 
values observed across five different years (Table 5) in our mixed effect model could be associated with the combined intra- and inter-block estimate of the treatment effects (i.e., cultivars effects) [46].

All eight cultivars produced substantial seed yields in 2011, 2014, and 2015. Among all cultivars, Columbia and Ligena produced the highest (1204 $\left.\mathrm{kg} \mathrm{ha}^{-1}\right)$ and lowest $\left(412 \mathrm{~kg} \mathrm{ha}^{-1}\right)$ seed yield in 2011, compared to their average seed yield $\left(751 \mathrm{~kg} \mathrm{ha}^{-1}\right)$. Seed yields in 2014 and 2015 were consistent among the different cultivars (Table 5). However, a higher seed yield production was obtained by Celine, Columbia, and Yellowstone in the drier years of 2012 and 2013, by Calena in 2012, and Suneson in 2013, compared to their average seed yield in the respective years. The seed yields for $C$. sativa across the different growing conditions ranged from $425-2867 \mathrm{~kg} \mathrm{ha}^{-1}[35,56]$, which agreed with the seed yield range observed in this study. The results from this study suggested that Calena, Celine, Columbia, and Yellowstone might be better suited for dryland production than the other tested cultivars, but additional trials under semi-arid and arid conditions are needed to validate this claim. Notably, these results were in partial agreement with a three-year study that showed that both Calena and Celine displayed the greatest mean seed yields, compared to 16 other varieties across six different Pacific Northwest locations [29].

\subsection{Biomass Yield and Harvest Indices}

Above ground biomass could provide benefits as a soil amendment that increases organic matter in the soil, which is advantageous in semi-arid and arid areas because it can increase the soil water absorption capacity. However, C. sativa leaves little field residue and no tillage or minimal tillage is recommended after harvest, to avoid or reduce soil erosion [28]. Biomass production results showed that Blaine Creek produced the highest mean above ground biomass over five years, followed by Calena and Columbia. These three cultivars were ranked highest in terms of biomass yield, although they were not statistically significant (Table 3). Notably, above ground biomass displayed the greatest year-to-year variation (and least statistical significance), which might be a result of the dynamic response of vegetative growth to water availability and genotypic differences in water uptake and water-use efficiency. The large amount of dispersion among the means of different cultivars (coefficient of variation $=59.53$ ) and lower statistical power for the biomass yield across five years (Table 5) would likely be plausible reasons for not exhibiting statistical differences among the eight $C$. sativa cultivars across five years [46,49].

The harvest index provided a useful measure to compare yields based on reproductive efficiency. Harvest indices have been reported for $C$. sativa and were within the range of $0.25-0.51$ [35]. The higher seed yields in 2011 and 2015 resulted in mean harvest indices of 0.15 and 0.18 , respectively. The lower harvest indices in the current study was likely due to the lower seed yields observed, as compared to other studies with higher available precipitation or irrigation rates [35]. Higher harvest indices in our study with higher irrigation rates (2014 and 2015) or higher ambient precipitation events (2011 and 2015) was consistent with the other studies, suggesting greater carbon allocation towards seed [58]. For example, the highest harvest index was observed in $2014(0.21)$ when the greatest amount of irrigation was applied $(385 \mathrm{~mm})$, reinforcing the positive impact of water availability upon improved reproductive efficiency. Columbia, Cheyenne, and Suneson exceeded the mean harvest indices in four, four, and three years of the five-year trial, respectively, and were ranked as the top three cultivars (Table 6). Notably, the harvest indices of Celine and Yellowstone exceeded the mean harvest index in, both of the drier years, 2012 and 2013, illustrating the resilience of these cultivars to water limitation.

\subsection{Oil Content, Oil, and Biodiesel Yield}

Oil content, which is one of the key determinants of oil and biodiesel production, is mostly affected by the genotype of the crop, and environmental and managemental conditions. There were no significant differences in oil content among the different cultivars, similar to the results reported from the previous study [33]. However, Calena, Columbia, and Blaine Creek showed the greater five-year mean seed oil content. Notably, the mean seed oil content was generally higher in the years that 
corresponded to the higher natural precipitation (2011 and 2015) or to the higher amount of irrigation water applied (2014 and 2015). The range of C. sativa seed oil content observed in this study was within the range reported in the previous literature [12,23-25,27,29,32,35,37], but it was lower than the C. sativa seed oil content reported by McVay and Khan [31]. The lower C. sativa oil content reported in our study was most likely due to water deficit, which was consistent with the observations made by other studies $[18,35,37,56]$. The results from this study suggest that Columbia, Blaine Creek, Suneson and Ligena might perform well, under drier conditions; however, this study also points to the need for improving the oil content in available $C$. sativa cultivars.

Oil yield, which is the product of oil content and overall seed yield, also depends upon the genotypes used, environmental conditions, and plot management practices. Average oil yield increased by $23.8 \%$ for Columbia, across the five growing seasons and the eight $C$. sativa cultivars, although no differences were observed among the eight cultivars in this study (Table 3). Across five growing years, oil yield was highest in 2015, and lowest in 2011 and 2012 (Table 4). However, statistical power was sufficiently larger only in 2011, compared to the other years (data not shown). The smaller $p$-value in $2011(p<0.05)$ observed in the mixed model analysis could be the result of the increased statistical power associated with the combined intra- and inter-block estimate of the cultivar effects [46]. The increase in oil yield by $218 \%$ in 2015 , compared to the average of the other four growing seasons was likely due to the optimum weather conditions, particularly the accumulated seasonal precipitation. Although 2011 was considered the wetter year, precipitation occurred in June, which did not improve the seed yield and oil content of the $C$. sativa cultivars. Cumulative GDD over the growing season was higher in 2015, compared to the other growing seasons. Grain yield was more influential $(r=1$, data not shown) in oil and biodiesel yield, relative to oil content $(r=0.88$, data not shown), which was in agreement with the recent study conducted in a semi-arid environment of Northern Nevada [40]. That study also suggested that factors affecting seed yield and oil content could also affect oil and biodiesel production [40]. Oil and biodiesel yield observed in this study among different cultivars were lower than previous studies conducted under similar growing conditions $[35,56]$, but was within the estimated biodiesel range of $67.8-164 \mathrm{~L} \mathrm{ha}^{-1}[23,25]$. Regarding oil and biodiesel production, Columbia, Cheyenne, and Calena might be better suited for dryland production than other cultivars, but additional trials under arid conditions are needed to validate this claim.

\subsection{Related Studies}

The mean seed yields observed in our study ranged from $76-1583 \mathrm{~kg} \mathrm{ha}^{-1}$ and were within the ranges of the yields reported (424-1791 $\mathrm{kg} \mathrm{ha}^{-1}$ ) for both irrigated and rainfed locations of the Western United States. The results were also comparable to three other irrigated field trials conducted under dryland conditions in Maricopa, AZ [36] and Scottsbluff, NE [27]. The mean annual precipitation in Reno, NV (165.1 mm) was slightly higher than that in Maricopa, AZ (137.2 mm), but markedly less than that in Scottsbluff, NE $(401.3 \mathrm{~mm}$ ). However, the total water applied (with irrigation) in the current study $(337.8 \mathrm{~mm}$ ) was very similar to that used in Maricopa, AZ (342.9 mm), but the mean seed yields were 1.54-fold higher than the current study, perhaps due to the different irrigation methods used. The Maricopa, AZ study used surface irrigation, measured by propeller flow meters and volumetric soil water contents, monitored by neutron moisture gauges [36]. In contrast, the Scottsbluff, NE study used greater irrigation rates $(431.8 \mathrm{~mm})$ supplied by an overhead linear-move sprinkler system, which resulted in 1.37-fold higher mean seed yields than the current study.

In contrast to C. sativa, Nevada's leading cash crop, Medicago sativa (alfalfa), requires large water inputs. Alfalfa's water demand has been estimated to be $7790 \mathrm{~mm}$ per season, on average, which is typically delivered by inefficient flood irrigation methods [59]. In contrast, this study's C. sativa, on average, required of $338 \mathrm{~mm}$ or approximately $4.3 \%$ of alfalfa's seasonal water demand. These differences show the potential value of developing alternative crops such $C$. sativa to modify habitual practices of growing high-input crops in arid regions, which require enormous quantities of scarce freshwater resources. However, a minimum level of irrigation above $400 \mathrm{~mm}$ is suggested by 
this and other related studies, to realize respectable seed yields and economic return on investment. However, wider adoption of low-water input oilseeds for biodiesel production is currently limited by low fossil petroleum prices and the lack of alternative uses for C. sativa [12].

\section{Conclusions}

This five-year field trial showed that C. sativa can be grown successfully in semi-arid and arid regions of the US, with applied irrigation. Overall, Columbia is highly recommended for use as an oilseed crop in such regions, because it displays the highest mean seed yield, harvest index, and estimated oil and biodiesel yield, over the five-year trial. However, Cheyenne, Calena, and Blaine Creek would also be suitable alternatives for Northern Nevada growing conditions, provided that adequate irrigation $(>400 \mathrm{~mm}$ ) can be provided to realize respectable seed, and oil and biodiesel yields.

Author Contributions: Conceptualization, J.C.C.; Data curation, R.H.L., D.N., M.A.M., and J.K.Q.S.; Formal analysis, R.H.L., D.N., M.A.M., and J.K.Q.S., and J.C.C.; Funding acquisition, J.K.Q.S.; J.C.C.; Investigation, R.H.L. and J.C.C.; Methodology, R.H.L., D.N., M.A.M., and J.K.Q.S., Project administration, J.C.C.; Resources, J.C.C.; Supervision, J.C.C. and J.K.Q.S.; Validation R.H.L., D.N., M.A.M., and J.K.Q.S. and J.C.C.; Visualization, R.H.L., J.C.C.; Writing original draft R.H.L.; Writing-review and editing, R.H.L., D.N., M.A.M., and J.K.Q.S., and J.C.C. All authors have read and agreed to the published version of the manuscript.

Funding: This work was supported by Hatch grant funding from the Nevada Agricultural Experiment Station under projects NEV-00372 and NEV-00384.

Acknowledgments: The authors would like to thank the following students who helped with field work: Tapas Acharjee, Norman Groves, Sang-ho Kang, Brian Kelly, Jeremiah Smith, Mohammed Forsad, Jason Caudill, Jordan Zager, Juri Kubac, Kieran Kubac, Jason Stubrich, Danielle Kinder, Kyle Lethcoe, Randy Pares, Austin Zell, Jesse Mayer, Brittany Blair, and Karmen Swanson. The authors would like to thank Lisa Petrusa for critical reading of the manuscript. The authors also would like to thank Russell S. Karow from the Department of Crop and Soil Science, Oregon State University, for kindly supplying the seed materials to conduct this study.

Conflicts of Interest: The authors declare no conflict of interest. The funders had no role in the design of the study; in the collection, analysis, or interpretation of data; in the writing of the manuscript, or in the decision to publish the results.

\section{References}

1. Putnam, D.H.; Budin, J.T.; Field, L.A.; Breene, W.M. Camelina: A promising low-input oilseed. In New Crops; Wiley: New York, NY, USA, 1993; pp. 314-321.

2. Zubr, J. Oil-seed crop: Camelina sativa. Ind. Crops Prod. 1997, 6, 113-119. [CrossRef]

3. Berti, M.; Gesch, R.; Eynck, C.; Anderson, J.; Cermak, S. Camelina uses, genetics, genomics, production, and management. Ind. Crops Prod. 2016, 94, 690-710. [CrossRef]

4. Colombini, S.; Broderick, G.A.; Galasso, I.; Martinelli, T.; Rapetti, L.; Russo, R.; Reggiani, R. Evaluation of Camelina sativa (L.) Crantz meal as an alternative protein source in ruminant rations. J. Sci. Food Agric. 2014, 94, 736-743. [CrossRef] [PubMed]

5. Moser, B.R.; Vaughn, S.F. Evaluation of alkyl esters from Camelina sativa oil as biodiesel and as blend components in ultra low-sulfur diesel fuel. Bioresourc. Technol. 2010, 101, 646-653. [CrossRef]

6. Moser, B.R. Camelina (Camelina sativa L.) oil as a biofuels feedstock: Golden opportunity or false hope? Lipid Technol. 2010, 22, 270-273. [CrossRef]

7. Ciubota-Rosie, C.; Ruiz, J.R.; Ramos, M.J.; Pérez, Á. Biodiesel from Camelina sativa: A comprehensive characterisation. Fuel 2013, 105, 572-577. [CrossRef]

8. Shonnard, D.R.; Williams, L.; Kalnes, T.N. Camelina-derived jet fuel and diesel: Sustainable advanced biofuels. Environ. Prog. Sustain. Energy 2010, 29, 382-392. [CrossRef]

9. Keske, C.M.; Hoag, D.L.; Brandess, A.; Johnson, J.J. Is it economically feasible for farmers to grow their own fuel? A study of Camelina sativa produced in the western United States as an on-farm biofuel. Biomass Bioenerg. 2013, 54, 89-99. [CrossRef]

10. Robinson, R.G. Camelina: A Useful Research Crop. and A Potential Oilseed Crop; Station Bulletin 579-1987; Minnesota Agricultural Experiment Station, University of Minnesota: St. Paul, MN, USA, 1987; pp. 1-12.

11. Dobre, P.; Jurcoane, S.; Matei, F.; Stelica, C.; Farcas, N.; Moraru, A.C. Camelina sativa as a double crop using the minimal tillage system. Rom. Biotechnol. Lett. 2014, 9, 9190-9195. 
12. Obour, A.K.; Chen, C.; Sintim, H.Y.; McVay, K.; Lamb, P.; Obeng, E.; Mohammed, Y.A.; Khan, Q.; Afshar, R.K.; Zheljazkov, V.D. Camelina sativa as a fallow replacement crop in wheat-based crop production systems in the US Great Plains. Ind. Crops Prod. 2018, 111, 22-29. [CrossRef]

13. Berti, M.; Samarappuli, D.; Johnson, B.L.; Gesch, R.W. Integrating winter camelina into maize and soybean cropping systems. Ind. Crops Prod. 2017, 107, 595-601. [CrossRef]

14. Chen, C.; Bekkerman, A.; Afshar, R.; Neill, K. Intensification of dryland cropping systems for bio-feedstock production: Evaluation of agronomic and economic benefits of Camelina sativa. Ind. Crops Prod. 2015, 71, 114-121. [CrossRef]

15. NASS. National Agricultural Statistics Service, USDA. Available online: https://www.nass.usda.gov/ (accessed on 11 May 2018).

16. Lindenmayer, R.B.; Hansen, N.C.; Brummer, J.; Pritchett, J.G. Deficit irrigation of alfalfa for water-savings in the Great Plains and Intermountain West: A review and analysis of the literature. Agron. J. 2011, 103, 45-50. [CrossRef]

17. Koenig, R.; Hurst, C.; Barnhill, J.; Kitchen, B.; Winger, M.; Johnson, M. Fertilizer Management for Alfalfa AG-FG-01; Utah State University Extension; Utah State University: Logan, UT, USA, 1999; pp. 1-5.

18. Hunsaker, D.J.; French, A.N.; Thorp, K.R. Camelina water use and seed yield response to irrigation scheduling in an arid environment. Irrig. Sci. 2013, 31, 911-929. [CrossRef]

19. Budin, J.T.; Breene, W.M.; Putnam, D.H. Some compositional properties of camelina (Camelina sativa L. Crantz) seeds and oils. J. Am. Oil Chem. Soc. 1995, 72, 309-315. [CrossRef]

20. Soroka, J.; Olivier, C.; Grenkow, L.; Séguin-Swartz, G. Interactions between Camelina sativa (Brassicaceae) and insect pests of canola. Can. Entomol. 2015, 147, 193-214. [CrossRef]

21. Mohammed, Y.A.; Chen, C.; Afshar, R.K. Nutrient requirements of camelina for biodiesel feedstock in central Montana. Agron. J. 2017, 109, 309-316. [CrossRef]

22. Séguin-Swartz, G.; Eynck, C.; Gugel, R.K.; Strelkov, S.E.; Olivier, C.Y.; Li, J.L.; Klein-Gebbinck, H.; Borhan, H.; Caldwell, C.D.; Falk, K.C. Diseases of Camelina sativa (false flax). Can. J. Plant. Pathol. 2009, 31, 375-386. [CrossRef]

23. Sintim, H.Y.; Zheljazkov, V.D.; Obour, A.K.; Garcia y Garcia, A.; Foulke, T.K. Influence of nitrogen and sulfur application on camelina performance under dryland conditions. Ind. Crops Prod. 2015, 70, 253-259. [CrossRef]

24. Wysocki, D.J.; Chastain, T.G.; Schillinger, W.F.; Guy, S.O.; Karow, R.S. Camelina: Seed yield response to applied nitrogen and sulfur. Field Crops Res. 2013, 145, 60-66. [CrossRef]

25. Sintim, H.Y.; Zheljazkov, V.D.; Obour, A.K.; Garcia y Garcia, A.; Foulke, T.K. Evaluating agronomic responses of camelina to seeding date under rain-fed conditions. Agron. J. 2016, 108, 349-357. [CrossRef]

26. Neupane, D.; Solomon, J.K.Q.; Mclennon, E.; Davison, J. Sowing date and sowing method influence on camelina cultivars grain yield, oil concentration, and biodiesel production. Food Energy Secur. 2019, 8, e00166. [CrossRef]

27. Pavlista, A.D.; Isbell, T.A.; Baltensperger, D.D.; Hergert, G.W. Planting date and development of spring-seeded irrigated canola, brown mustard and camelina. Ind. Crops Prod. 2011, 33, 451-456. [CrossRef]

28. Schillinger, W.F.; Wysocki, D.J.; Chastain, T.G.; Guy, S.O.; Karow, R.S. Camelina: Planting date and method effects on stand establishment and seed yield. Field Crops Res. 2012, 130, 138-144. [CrossRef]

29. Guy, S.O.; Wysocki, D.J.; Schillinger, W.F.; Chastain, T.G.; Karow, R.S.; Garland-Campbell, K.; Burke, I.C. Camelina: Adaptation and performance of genotypes. Field Crops Res. 2014, 155, 224-232. [CrossRef]

30. Aiken, R.; Baltensperger, D.; Krall, J.; Pavlista, A.; Johnson, J. Planting methods affect emergence, flowering and yield of spring oilseed crops in the US central High Plains. Ind. Crops Prod. 2015, 69, 273-277. [CrossRef]

31. McVay, K.A.; Khan, Q.A. Camelina yield response to different plant populations under dryland conditions. Agron. J. 2011, 103. [CrossRef]

32. Obou, A.K.; Obeng, E.; Mohammed, Y.A.; Ciampitti, I.A.; Durrett, T.P.; Aznar-Moreno, J.A.; Chen, C. Camelina seed yield and fatty acids as influenced by genotype and environment. Agron. J. 2017, 109. [CrossRef]

33. Mohammed, Y.A.; Chen, C.; Lamb, P.; Afshar, R.K. Agronomic evaluation of Camelina (Camelina sativa L. Crantz) cultivars for biodiesel feedstock. Bioenergy Res. 2017, 10, 792-799. [CrossRef]

34. Obour, A.K.; Sintim, H.Y.; Obeng, E.; Jeliazkov, D.V. Oilseed camelina (Camelina sativa L Crantz): Production systems, prospects and challenges in the USA Great Plains. Adv. Plants Ag. Res. 2015, 2, 00042. [CrossRef]

35. Pavlista, A.D.; Hergert, G.W.; Margheim, J.M.; Isbell, T.A. Growth of spring camelina (Camelina sativa) under deficit irrigation in Western Nebraska. Ind. Crops Prod. 2016, 83, 118-123. [CrossRef]

36. Hunsaker, D.J.; French, A.N.; Clarke, T.R.; El-Shikha, D.M. Water use, crop coefficients, and irrigation management criteria for camelina production in arid regions. Irrig. Sci. 2011, 29, 27-43. [CrossRef] 
37. Neupane, D.; Solomon, J.K.Q.; Mclennon, E.; Davison, J.; Lawry, T. Camelina production parameters response to different irrigation regimes. Ind. Crops Prod. 2020, 148. [CrossRef]

38. George, N.; Hollingsworth, J.; Yang, W.-R.; Kaffka, S. Canola and camelina as new crop options for cool-season production in California. Crop. Sci. 2017, 57, 693-712. [CrossRef]

39. Neupane, D.; Solomon, J.K.Q.; Davison, J.; Lawry, T. Nitrogen source and rate effects on grain and potential biodiesel production of camelina in the semiarid environment of northern Nevada. Glob. Chang. Biol. Bioenergy 2018, 10, 861-876. [CrossRef]

40. Soil Survey Staff. Natural Resources Conservation Service, United States Department of Agriculture. Available online: https://websoilsurvey.sc.egov.usda.gov/ (accessed on 11 May 2018).

41. WRCC, D. Western Regional Climate Center, Desert Research Institute Weather Station. Available online: https://wrcc.dri.edu/ (accessed on 15 February 2020).

42. Yobi, A.; Schlauch, K.A.; Perryman, B.; Oliver, M.J.; Cushman, J.C. Biomass production, nutritional and mineral content of desiccation-sensitive and desiccation-tolerant species of Sporobolus under multiple irrigation regimes. J. Agron. Crop. Sci. 2013, 199, 309-320. [CrossRef]

43. Gesch, R.W.; Johnson, J.M.F. Water use in camelina-soybean dual cropping systems. Agron. J. 2015, 107, 1098-1104. [CrossRef]

44. Kemp, W.H. Biodiesel: Basics and Beyond: A Comprehensive Guide to Production and Use for the Home and Farm; Aztext Press: Tamworth, ON, Canada, 2006.

45. SAS Institute, Inc. Base SAS ${ }^{\circledR} 9.4$ Procedures Guide. SAS Institute, Inc.: Cary, NC, USA, 2015.

46. Stroup, W.W.; Milliken, G.A.; Claassen, E.A.; Wolfinger, R.D. SAS ${ }^{\circledR}$ for Mixed Models: Introduction and Basic Applications; SAS Institute Inc.: Cary, NC, USA, 2018.

47. Kupzyk, K.A. The Effects of Simplifying Assumptions in Power Analysis. Ph.D. Thesis, University of Nebraska-Lincoln, Lincoln, NE, USA, 2011.

48. Gent, D.H.; Esker, P.D.; Kriss, A.B. Statistical power in plant pathology research. Phytopathology 2018, 108, 15-22. [CrossRef]

49. Stroup, W.W. Power analysis based on spatial effects mixed models: A tool for comparing design and analysis strategies in the presence of spatial variability. J. Agric. Biol. Environ. Stat. 2002, 7, 491-511. [CrossRef]

50. Piepho, H.P.; Michel, V.; Williams, E. Neighbor balance and evenness of distribution of treatment replications in row-column designs. Biom. J. 2018, 60, 1172-1189. [CrossRef]

51. Dai, A.; Zhao, T.; Chen, J. Climate change and drought: A precipitation and evaporation perspective. Curr. Clim. Chang. Rep. 2018, 4, 301-312. [CrossRef]

52. Barnett, T.P.; Adam, J.C.; Lettenmaier, D.P. Potential impacts of a warming climate on water availability in snow-dominated regions. Nature 2005, 438, 303-309. [CrossRef] [PubMed]

53. Challinor, A.J.; Watson, J.; Lobell, D.B.; Howden, S.M.; Smith, D.R.; Chhetri, N. A meta-analysis of crop yield under climate change and adaptation. Nat. Clim. Chang. 2014, 4, 287-291. [CrossRef]

54. NOAA. National Weather Service. Available online: http://www.nws.noaa.gov/climate/index.php?wfo=rev (accessed on 15 February 2020).

55. Kamkar, B.; Daneshmand, A.R.; Ghooshchi, F.; Shiranirad, A.H.; Langeroudi, A.R.S. The effects of irrigation regimes and nitrogen rates on some agronomic traits of canola under a semiarid environment. Agric. Water Manag. 2011, 98, 1005-1012. [CrossRef]

56. Hergert, G.W.; Margheim, J.F.; Pavlista, A.D.; Martin, D.L.; Isbell, T.A.; Supalla, R.J. Irrigation response and water productivity of deficit to fully irrigated spring camelina. Agric. Water Manag. 2016, 177, 46-53. [CrossRef]

57. Santos, R.F.; Bassegio, D.; Almeida Silva, M.D. Productivity and production components of safflower genotypes affected by irrigation at phenological stages. Agric. Water Manag. 2017, 186, 66-74. [CrossRef]

58. Torrion, J.A.; Stougaard, R.N. Impacts and limits of irrigation water management on wheat yield and quality. Crop. Sci. 2017, 57, 3239-3251. [CrossRef]

59. Davison, J.; Solomon, J.; Lawry, T. Alfalfa Variety Trial in Western Nevada, Initial Results; University of Nevada Cooperative Extension; University of Nevada: Reno, NV, USA, 2016; pp. 1-7.

(C) 2020 by the authors. Licensee MDPI, Basel, Switzerland. This article is an open access article distributed under the terms and conditions of the Creative Commons Attribution (CC BY) license (http://creativecommons.org/licenses/by/4.0/). 